\title{
THEORETICAL AND PRACTICAL ASPECTS OF THE FINANCIAL DIAGNOSIS FOR THE ROMANIAN PUBLIC INSTITUTIONS
}

\author{
Teodor $H A D A^{1}$ \\ Iulia $I U G A^{2}$ \\ Mihai $C \breve{A R} U T^{3}$
}

\begin{abstract}
The need for efficient public management, a coherent and responsible local autonomy and the need to increase the efficacy and the capacity of the administration are the elements and factors that determine us to approach the idea of measuring the performance, especially the financial performance. Thus, we centred our analysis around the present tendencies of the public management and around the problem of the performance, passing from general (a given model in the Romanian legislation) to particular (the performance in the public sector, the measurement and the characteristics of the financial performance indicators for several Romanian village halls). Aim (general objective): 1. Testing the measurement indicators for the financial performance of the Romanian local authorities in order to establish the financial position of the public institutions. The testing was performed on three territorial administrative entities.
\end{abstract}

Key words: financial diagnosis, financial situations, indicators, budgetary account

JEL codes: H20, H21, C58

\section{Introduction}

To a macro economical level, in the Romanian public administration, due to the decentralisation process, the city halls, the village halls, and the local and county councils became financing entities with a high degree of autonomy. The projects and the programs supported by them, and also the decrees and all the other public decisional acts must reach high standards of efficacy and performance. The communities are in economic competition. Fighting for the wellbeing of the citizens or to attract high-qualified working force, the financial and fiscal conditionality of the local authorities have a high degree of uniformisation. The differences are given by the size of the territorial administrative entity and by its degree of economic development.

To a micro economical level (local administration), an analysis of the financial performance is important from 2 points of view:

1. For the basis of the internal policy on the taxation level (revenues) and also on the costs perspective

2. For the establishment of the investments level of the local authority.

A very important aspect is that the integrity of an analysis model, including that for the financial performance of the local authorities, depends a lot on the accuracy and the availability of the data. To a national level, in the dedicated literature, we were not able to identify analysis models for the financial performance of the Romanian local authorities, in order to establish the financial position of the public institutions - territorial administrative entities. To an international level, we identify numerous measuring models: the model developed by Groves, Godsey, and Shulman, (1981); the model developed by Kloha, Weissert, and Kleine (2005); the model developed by Zafra

\footnotetext{
1 "Bogdan Vodă” University Cluj-Napoca, e-mail:teohada@yahoo.com

2 “1 Decembrie 1918” University Of Alba Iulia, Faculty Of Economic Science, e-mail:iuga_iulia@yahoo.com

3 “1 Decembrie 1918” University Alba Iulia, e-mail: mihaimihnea@ gmail.com
}

DOI: 10.29302/oeconomica.2018.20.2.7 
Gómez, J.L., López Hernández, and Hernández Bastida (2009). For these models, some authors prefers the strict use of the financial indicators, while others creates complex models using a combination of factors and indicators, which are financial, economic, social, and organisational. We observed the inexistence of an optimal or generalised methodology for the evaluation of the financial performance of a local entity. Moreover, we cannot affirm that the practitioners and the specialists involved in the development of the models managed to prove the superiority of their models compared to other models. Unable to identify a predominant model, we tried to group them depending to their similar characteristics and structures.

Regarding the financial performance, starting from the supposition that different territorial administrative entities acts in different contexts and conditions, the comparison of the results is made between units with similar characteristics (Zafra-Gomez 2009).

\section{The financial diagnosis}

The accountancy of the public institutions ensures information for the authorising officers related to the execution of the income and expenditure budgets, the result of the budgetary execution, the managed patrimony, the economic result, the cost of the budget approved program, and also information for the establishing of the yearly general account for the state budget execution and for the establishing of the yearly general account for the execution of the budget of the state social security and special funds.

The diagnosis is a component of the management system, permitting the information prior to the establishing of the objectives and, in the same time, the achievement of the objectives. To diagnose does not mean to describe, but to identify the key-variables of the phenomena state and dynamics and to study their interaction in order to determine the progress objective of the enterprise. The progress sources that are possible to be identified come from the incoherence, the vulnerabilities and the potentialities highlighted by the diagnosis.

The financial diagnosis is an instrument available for the managers of the territorial administrative entities and allows the formulation of qualitative and/or quantitative value judgements on the state, the dynamic and the perspectives of a Territorial Administrative Entity, and the highlighting of its forces and weaknesses and of its development capacity.

It is known the fact that the financial diagnosis is an important component of the global diagnosis, which, by the system of the presented indicators, reflects the performances of the territorial administrative entity to a certain time. Disregarding the number of indicators used in the financial diagnosis, the results cannot be conclusive without a correlation with the other components of the global diagnosis.

The investigation of the economic reality requires a specific approach, correlating the classic vision based on the knowledge of the causality relations and of the internal laws of the formation and evolution of the phenomena, and the systemic approach, oriented to their study in a continuously changing environment. Such approach allows not only a correct evaluation of the status quo, but also the identification of the development vulnerabilities and opportunities, essential for the management decisions.

The word "diagnosis" is of Greek origin and means "capable to discern". It has in the local administration the same meaning as in medicine. Disregarding the field of activity, the diagnosis imposes, as prior phase, the complex analysis of the formation and modifying mechanism of the specific phenomena.

\section{The system of factors explaining the formation and/or modification of the results}

The pertinence of the financial diagnosis is conditioned by the knowledge of the factors acting on a phenomenon and its nature, and on the mechanism that contributes to the formation and modification of the results. Usually, the factors do not act isolated, but in interdependence, correlated in a system of strong connections. Their identification requires the precise knowledge of 
the formation ways of the result, of the specific causal connections, as well of the economical-social and concurrence environment. In the current practice, the privileged source of information to the level of territorial administrative entity consists, especially for the financial analysts, of:

A. balance sheet;

B. the economic outturn account;

C. the situation of the cash flows;

D. the situation of the modifications in the structure of the assets/capital;

E. annexes to the financial situations, including accounting policies and explanatory notes;

F. the budgetary account.

The financial situations of the public institutions are represented by official documents presenting the position of the assets in the administration of the state and of the territorial administrative entities, and also the revenues and expenditure execution. They are established according to the specification of the Ministry for Public Finances and are approved by the minister of public finances.

According to the provisions of the Order of the minister of public finances no. 1.917/2005, for the approval of the Methodological norms on the organisation and the keeping of the accounts of the public institutions, the Chart of accounts for the public institutions and its implementation instructions, the ministries, other specialised organisms of the central public administration, other public authorities, the autonomous public institutions and the territorial administrative entities, whose managers are main authorising officers, submit to the Ministry for Public Finances or to the general directions of the county public finances or of the municipality Bucharest, a copy of the financial situations at every three months and yearly, according to the established norms and terms.

\section{The structure of the financial situations}

The financial situations to 31.12.2017 are reported according to the provisions of O.M.F.P. no. 1177/2018 for the approval of the Methodological norms on the report and submission of the financial situations of the Public institutions to $31^{\text {st }}$ of December 2017.

The financial situations for every three months and for entire year have the following structure:

1. The balance sheet,

2. The economic outturn account,

3. The situation of the cash flows,

4. The situation of the modifications in the structure of the assets/capital,

5. The budgetary account,

6. Annexes including accounting policies and explanatory notes.

\section{The balance sheet}

The balance sheet is a synthesis accounting document presenting the elements related to assets, debts and equity of the public institution at the end of the report period, as well as in other legal situations.

The assets are presented in the balance sheet depending on the ascendant degree of their liquidity, while the debts are presented depending on the ascendant degree of their chargeability.

An asset represents a resource controlled by the public institution, as a result of past events, expected to generate future economic benefits for the institution and with a cost that can be evaluated credibly by the territorial administrative entity.

A debt represents a current obligation of the public institution, generated by past events, and expected to result, through settlement, into an outflow of resources incorporating economic benefits.

The assets and the current debts are presented in the balance sheet separately from the non-current assets and debts. 
The equity represents the residual interest of the state or of the territorial administrative entities, as owners of the assets of a public institution after the deduction of all the debts. The equities are also called net assets or net patrimony and are determined as difference between assets and debts.

\section{The economic outturn account}

The revenues and the expenditure appearing outside the current activities of the public institution are presented as extraordinary revenues and extraordinary expenditure. They result from transactions or events that clearly different from the current activities of the institution and that are not expected to be repeated frequently or on a regular base.

The current activities are developed by a public institution in order to reach its line of work, established according to the organisation and working procedures. In order to establish if an event or an activity is clearly delimitated by the current activities of the entity, the nature of the element or of the transaction is taken into consideration rather than the expected frequency of such events.

The economic outturn account presents the situation of the revenues, financing and expenditure during the current financial year. The revenues and the financing are presented classified after their nature or source, disregarding if they were collected or not. The expenditure is classified after their nature or destination, disregarding if they were paid or not.

The economic outturn account also presents the calculated revenues (e.g. revenues from the write-back of the provisions and value adjustments), which do not involve their collection, and also the calculated expenditure (e.g. expenditure for depreciation, provisions and adjustments), which do not involve their payment.

The value corresponding to each element from the previous financial year must be presented for each element from the financial outturn account. The form of the economic outturn account cannot be modified from one financial year to another. The completion of the account is necessary because it offers supplementary information to the balance sheet on the structure of the elements that generate a specific result.

\section{The budgetary account}

The budgetary account contains all the financial operations during the financial year related to the collected revenues and the payments made by the territorial administrative entity, corresponding to the approved structure of the budget. It includes:

a) Information on revenues:

$>$ Initial budgetary provisions, final budgetary provisions;

$>$ Established entitlements;

$>$ Collected revenues;

$>$ Established entitlements to be collected;

b) Information on expenditure:

$>$ Initial budgetary appropriations, final budgetary appropriations;

$>$ Budgetary commitments;

$>$ Legal commitments;

$>$ Payments made by the territorial administrative entity;

$>$ Legal commitments to be paid;

$>$ Effective costs (costs, resources consumption);

c) Information on the result of the financial year (collected revenues minus payments made by the territorial administrative entity).

The budgetary account is completed based on data collected by the territorial administrative entity from the debts and credit cash flows, which must correspond to the ones in the bank or treasury accounts. 
We present as follows The situation of the indicators on the local budgetary execution for 2017 to the territorial administrative entity Pianu.

Table no. 1

The indicators on the local budgetary execution for 2017 to the territorial administrative entity Pianu - revenues:

\begin{tabular}{|c|c|c|c|c|c|}
\hline \multicolumn{6}{|c|}{ REVENUES } \\
\hline $\begin{array}{l}\text { Ref. } \\
\text { no. }\end{array}$ & Indicator & Calculation formula & $\begin{array}{c}\text { Perce } \\
\text { n } \\
\text { tage }\end{array}$ & Sum & INDICATOR \\
\hline \multirow[t]{2}{*}{1} & \multirow{2}{*}{$\begin{array}{l}\text { The degree of collected } \\
\text { revenues }\end{array}$} & Total collected revenues & \multirow[t]{2}{*}{$\%$} & $10,222,395$ & \multirow[t]{2}{*}{$48.76 \%$} \\
\hline & & Total scheduled revenues & & $20,966,080$ & \\
\hline \multirow[t]{2}{*}{2} & \multirow{2}{*}{$\begin{array}{l}\text { The degree of collected own } \\
\text { revenues }\end{array}$} & Collected own revenues & \multirow[t]{2}{*}{$\%$} & $2,616,617$ & \multirow[t]{2}{*}{$89.2 \%$} \\
\hline & & Scheduled own revenues & & $2,933,450$ & \\
\hline \multirow[t]{2}{*}{3} & \multirow{2}{*}{$\begin{array}{l}\text { The financing degree from } \\
\text { own revenues }\end{array}$} & Collected own revenues & \multirow[t]{2}{*}{$\%$} & $2,616,617$ & \multirow[t]{2}{*}{$25.6 \%$} \\
\hline & & Total collected revenues & & $10,222,395$ & \\
\hline \multirow[t]{2}{*}{4} & \multirow[t]{2}{*}{ The self-financing degree } & $\begin{array}{lcc}\begin{array}{l}\text { Collected own } \\
\text { (excluding quota) }\end{array} & \text { revenues } \\
\end{array}$ & \multirow[t]{2}{*}{$\%$} & $1,036,323$ & \multirow[t]{2}{*}{$10.14 \%$} \\
\hline & & Total collected revenues & & $10,222,395$ & \\
\hline \multirow[t]{2}{*}{5} & \multirow{2}{*}{$\begin{array}{l}\text { Collected own revenues per } \\
\text { capita }\end{array}$} & Collected own revenues & \multirow[t]{2}{*}{$\%$} & $2,616,617$ & \multirow[t]{2}{*}{723.22} \\
\hline & & Inhabitants number & & 3,618 & \\
\hline \multirow[t]{2}{*}{6} & \multirow[t]{2}{*}{$\begin{array}{l}\text { The collecting degree of the } \\
\text { property taxes }\end{array}$} & $\begin{array}{lll}\begin{array}{l}\text { Revenues from } \\
\text { property taxes }\end{array} & \text { collected } \\
\end{array}$ & \multirow[t]{2}{*}{$\%$} & 747,613 & \multirow[t]{2}{*}{$120.5 \%$} \\
\hline & & $\begin{array}{l}\text { Revenues from programmed } \\
\text { property taxes }\end{array}$ & & 620,450 & \\
\hline \multirow[t]{2}{*}{7} & \multirow{2}{*}{$\begin{array}{l}\text { The dependency degree of } \\
\text { the local budget to the state } \\
\text { budget }\end{array}$} & $\begin{array}{l}\begin{array}{l}\text { Revenues from state budget } \\
\text { sources }\end{array} \\
\end{array}$ & \multirow[t]{2}{*}{$\%$} & $5,421,836$ & \multirow[t]{2}{*}{$53.04 \%$} \\
\hline & & Total collected revenues & & $10,222,395$ & \\
\hline \multirow[t]{2}{*}{8} & \multirow[t]{2}{*}{$\begin{array}{l}\text { The degree of decisional } \\
\text { autonomy }\end{array}$} & $\begin{array}{ll}\begin{array}{l}\text { Collected } \\
\text { revenues }\end{array} & \text { depersonalised } \\
\end{array}$ & \multirow[t]{2}{*}{$\%$} & $3,179,617$ & \multirow[t]{2}{*}{$31.1 \%$} \\
\hline & & Total collected revenues & & $10,222,395$ & \\
\hline 9 & $\begin{array}{l}\text { The yearly estimation of } \\
\text { fiscal revenues }\end{array}$ & & & & \\
\hline \multirow[t]{2}{*}{ a) } & \multirow{2}{*}{$\begin{array}{l}\text { The collection degree of the } \\
\text { fiscal revenues during the } \\
\text { former year (calculated on a } \\
\text { three-months base) }\end{array}$} & $\begin{array}{l}\text { Fiscal revenues cumulated in the } \\
\text { former year (trimesters I,II,III) }\end{array}$ & $\%$ & 713,349 & 1 \\
\hline & & $\begin{array}{l}\text { Total collected fiscal revenues in } \\
\text { the former year }\end{array}$ & & 713,349 & \\
\hline b) & $\begin{array}{l}\text { The yearly estimation of the } \\
\text { fiscal revenues }\end{array}$ & $\begin{array}{l}\text { Fiscal revenues cumulated for } \\
\text { the calculation year (trimesters } \\
\text { I,II,III) }\end{array}$ & $\%$ & $801,576.00$ & 1 \\
\hline & & Coefficient & & $801,576.00$ & \\
\hline
\end{tabular}

Source of data: the territorial administrative entity Pianu.

The degree of the revenues collection is determined as percentage report between the total collected revenues and the total programmed revenues for the reporting period. The degree of the own revenues collection is determined as percentage report between the collected own revenues and the total programmed own revenues for the reporting period. The financing degree from own revenues is determined as percentage report between the collected own revenues (including broken down quota from the income taxes) and the total of the collected revenues. The self-financing degree is determined as percentage report between the collected own revenues (exclusively broken down quota from the income taxes) and the total collected revenues. The collected own revenues per capita are determined as report between the collected own revenues (including broken down quota from the income taxes) and the inhabitants number in the territorial-administrative entity. The collection degree of property taxes is determined as percentage report between the collected revenues from property taxes and the programed revenues from property taxes for the reporting period. The dependence degree of the local budget to the state budget is determined as percentage 
report between the collections from state budget sources and total collections. The degree of decisional autonomy is determined as percentage report between the collected depersonalised revenues and the total revenues. The yearly estimation [E(vfl)] from local fiscal revenues (fiscal revenues minus the quota and the broken down sums from the VAT) is calculated according to the following procedure:

a) The coefficient of fiscal revenues [y(i)] in the former year (t-1) is calculated on a three months base, using the following formula:

$$
\mathrm{y}(\mathrm{i})=\frac{\sum_{i=1}^{n} \text { collected revenues trimester i year }(t-1)}{\text { ollected revenues year }(\mathrm{t}-1)}
$$

where:

$\mathrm{n}=$ the trimester of reference (I, II or III) for which the coefficient is calculated;

Collected revenues trim. i year $(\mathrm{t}-1)=$ the cumulated three-months based collected revenues related to the collected local fiscal revenues until the end of the trimester (n) of the former year ( $t-1)$ for which the coefficient is calculated;

$(\mathrm{t}-1)$ - the year previous to the calculated year;

Collected revenues year $(\mathrm{t}-1)=$ total collected revenues related to the local fiscal revenues (fiscal revenues minus the broken down quota and the broken down sums) to the end of the year previous to the calculation year.

b) The yearly estimation [Evfl)] from local fiscal revenues (fiscal revenues minus the broken down quota and the broken down sums), after the following formula:

$$
\mathrm{E}[\operatorname{vfl}(\mathrm{n})]=\frac{\sum_{i=1}^{n} \text { collected revenues trimester } \mathbf{i} \text { an } \mathbf{t}}{\mathrm{y}(\mathrm{i})}
$$

where:

$\mathrm{n}$ - the trimester of reference (I, II or III) when the estimation is made;

Collected revenues trimester $i$ an $(t)$ - the three-months based cumulated collected revenues related to the local fiscal revenues minus the broken down quota and the broken down sums until the end of the trimester for which the Estimation [Evfl)] is calculated;

$(\mathrm{t})$ - the calculation year of the yearly Estimation $[\mathrm{E}(\mathrm{vfl})]$ from fiscal revenues;

\begin{tabular}{|c|c|c|c|c|c|}
\hline \multicolumn{6}{|c|}{ EXPENSES } \\
\hline $\begin{array}{l}\text { Ref. } \\
\text { no. }\end{array}$ & Synthesis indicators & Calculation formula & & Sums & Percentage \\
\hline \multirow[t]{4}{*}{1} & \multirow[t]{4}{*}{ The rigidity of the expenses } & Payments related to staff & \multirow[t]{4}{*}{$\%$} & & \multirow[t]{4}{*}{$40.06 \%$} \\
\hline & & & & $3,114,584$ & \\
\hline & & Total payments & & & \\
\hline & & & & $7,774,168$ & \\
\hline \multirow[t]{4}{*}{2} & \multirow{4}{*}{$\begin{array}{l}\text { The weight of the functioning } \\
\text { section }\end{array}$} & Payments related to the functioning & \multirow[t]{4}{*}{$\%$} & & \multirow[t]{4}{*}{$72.48 \%$} \\
\hline & & section & & $5,634,947$ & \\
\hline & & Total payments & & & \\
\hline & & & & $7,774,168$ & \\
\hline \multirow[t]{3}{*}{3} & \multirow{3}{*}{$\begin{array}{l}\text { The weight of the } \\
\text { development section }\end{array}$} & Payments related to the development & \multirow[t]{3}{*}{$\%$} & & \multirow[t]{3}{*}{$27.52 \%$} \\
\hline & & section & & $2,139,221$ & \\
\hline & & Total payments & & $7,774,168$ & \\
\hline 4 & The weight of servicing public & The local servicing public debt & $\%$ & 0.00 & - \\
\hline
\end{tabular}

Table no. 2

The indicators on the local budgetary execution for 2017 to the territorial administrative entity Pianu - expenses: 


\begin{tabular}{|c|c|c|c|c|}
\hline & debt & Total payments & 0.00 & \\
\hline \multirow[t]{2}{*}{5} & $\begin{array}{l}\text { The deficit of the functioning } \\
\text { section }\end{array}$ & $\begin{array}{l}\begin{array}{l}\text { payments made by the } \\
\text { entity }+ \\
\text { outstanding } \\
\text { revenues }\end{array} \\
\text { payments) } \\
-\end{array}$ & - & - \\
\hline & $\begin{array}{l}\text { The excess of the functioning } \\
\text { section }\end{array}$ & $\begin{array}{l}\text { (payments made by the } \\
\begin{array}{l}\text { entity }+ \\
\text { outstanding } \\
\text { revenues }\end{array}\end{array}$ & 68,751 & - \\
\hline \multirow[t]{2}{*}{6} & $\begin{array}{l}\text { The deficit of the development } \\
\text { section }\end{array}$ & $\begin{array}{l}\begin{array}{l}\text { (payments made by the } \\
\text { outstanding } \\
\text { revenues }\end{array} \\
\text { revents }+ \\
-\end{array}$ & - & - \\
\hline & $\begin{array}{l}\text { The excess of the } \\
\text { development section }\end{array}$ & $\begin{array}{l}\begin{array}{l}\text { (payments made by the } \\
\text { outstanding } \\
\text { payments) } \\
\text { revenues }\end{array} \\
\end{array}$ & $2,379,477$ & - \\
\hline
\end{tabular}

Source of data: the territorial administrative entity Pianu

The rigidity of the expense is determined as percentage report between the staff expense and the total payments. The weight of the functioning section is determined as percentage report between the weight of the payments from the functioning section and the total payments. The weight of the development section is determined as percentage report between the weight of serving public debts and total payments made by the territorial administrative entity. The deficit (excess) in the functioning section is determined according to Law no. 273/2006. The deficit (excess) of the development section is also determined according to the same law.

\section{Analysis model}

From all the above presented indicators, we chose the most representative indicators for the financial diagnosis of the territorial administrative entity and for its management. We present them as follows, together with their score.

Table no. 3.

Explain the our analysis model

\begin{tabular}{|l|l|l|l|l|l|l|}
\hline Ref. & Indicator & \multicolumn{4}{l|}{ Score } & \multicolumn{4}{l|}{} \\
\cline { 3 - 6 } no. & & $\mathbf{2 0}$ & $\mathbf{4 0}$ & $\mathbf{6 0}$ & $\mathbf{8 0}$ & $\mathbf{1 0 0}$ \\
\hline 1 & The degree of revenues collection & $<30$ & $(30,40]$ & $(40,60]$ & $(60,80]$ & $>80$ \\
\hline 2 & The degree of own revenues collection & $<30$ & $(30,50]$ & $(50,70]$ & $(70,90]$ & $>90$ \\
\hline 3 & The degree of own revenues financing & $<40$ & $(40,70]$ & $(70,80]$ & $(80,90]$ & $>90$ \\
\hline 4 & The self-financing degree & $<40$ & $(40,70]$ & $(70,80]$ & $(80,90]$ & $>90$ \\
\hline 5 & The degree of property taxes collection & $<30$ & $(30,40]$ & $(40,60]$ & $(60,80]$ & $>80$ \\
\hline 6 & The dependence degree of the local budget to the state & $>80$ & {$[80,60)$} & $(60,40]$ & $(40,25]$ & $<25$ \\
\hline 7 & The degree of decisional autonomy & $<30$ & $(30,40]$ & $(40,60]$ & $(60,80]$ & $>80$ \\
\hline 8 & The rigidity of the expense & $>80$ & {$[80,60)$} & {$[60,40]$} & $(40,30]$ & $<30$ \\
\hline 9 & The weight of the functioning section & $>80$ & {$[80,60)$} & {$[60,40]$} & $(40,30]$ & $<30$ \\
\hline 10 & The weight of the development section & $<30$ & $(30,40]$ & $(40,60]$ & $(60,80]$ & $>80$ \\
\hline
\end{tabular}

The degree of revenues collection is the indicator that expresses the financing degree of the expense because the expense of the public institution is in the limit of the collected revenues; thus, we noted it with 5 as importance degree. The degree of own revenues collection expresses the efficacy of the public institutions in collecting their own revenues, which can be used for programs; thus, we noted it with 5 as importance degree. The degree of own revenues financing shows the weight of the own revenues in the total of the revenues from the local budget; thus, we noted it with 5 as importance degree. The self-financing degree shows the weight in the own revenues of the 
taxes collection established by the Ministry for Finance or the County Council; thus, we noted it with 5 as importance degree. The degree of property taxes collection indicates the efficacy in the collection of the property taxes established by the decision of the Local Council. Due to the fact that the own revenues are not entirely coming from property taxes, we noted it with 3 as importance degree. The dependence degree of the local budget to the state budget indicates the percentage for the completion of the local budget revenues with state budget revenues: - broken down amounts from VTA; amounts from broken down quota from the income tax for the equilibration of the local budgets; and subventions. Therefore, we noted it with 5 as importance degree. The degree of decisional autonomy shows the manner in which the public institutions can decide the spending of the sums from the local budget. The depersonalized revenues represents the sum of the own revenues, including the broken down sums from the VAT for the equilibration of the local budgets reported to the total revenues; thus, we noted it with 5 as importance degree. The rigidity of the expense expresses the spending destination of the public sums: for the staff or for material expense and investments. Based on the fact that the public institutions do not aim to generate profit and they also have a social role, we noted it with 4 as importance degree. The weight of the functioning section shows how much from the budget expense is used for functioning; therefore, we noted it with 5 as importance. The weight of the development section indicates how much from the budget expense is used for development and investments; thus, we noted it with 5 as importance. We noted later a coefficient of importance to each indicator, we correlated it with the score and, in the end, and we calculated the aggregated note. Depending on the aggregated note, the territorial administrative entities may be classified as follows:

Table no. 4

Establishing aggregated note

\begin{tabular}{|l|l|}
\hline $\begin{array}{l}\text { Aggregated note } \\
\text { (AN) }\end{array}$ & Result \\
\hline $0-20$ & Public institutions in bankruptcy \\
\hline $20-40$ & Public institutions with financial problems \\
\hline $40-60$ & Public institutions with a good financial condition \\
\hline $60-80$ & $\begin{array}{l}\text { Public institutions with a very good financial } \\
\text { condition }\end{array}$ \\
\hline $80-100$ & Public institutions financially autonomous \\
\hline
\end{tabular}

\begin{tabular}{|l|l|}
\hline Aggregated note $(\mathrm{AN})=\frac{\sum \boldsymbol{C} \boldsymbol{i x P a}}{\boldsymbol{C} \boldsymbol{i}}$ & $\begin{array}{l}\text { Where: } \mathrm{Ci}=\text { Coefficient of importance } \mathrm{Pa}= \\
\text { score }\end{array}$ \\
\hline
\end{tabular}

Using the presented model, we can establish the financial position of each territorial administrative entity.

Thus, we obtained the following values for three territorial administrative entities:

Table no. 5

The Territorial Administrative Entity Pianu:

\begin{tabular}{|l|l|l|l|l|}
\hline $\begin{array}{c}\text { Ref. } \\
\text { no. }\end{array}$ & \multicolumn{1}{|c|}{ Indicator } & $\begin{array}{c}\text { Coefficient } \\
\text { of } \\
\text { importance }\end{array}$ & \multicolumn{1}{|c|}{ Calculate value } & \multicolumn{1}{|c|}{ Score } \\
\hline 1 & The degree of revenues achievement & 5 & $48.76 \%$ & 60 \\
\hline 2 & The degree of revenues collection & 5 & $89.20 \%$ & 80 \\
\hline 3 & The degree of own revenues collection & 5 & $25.60 \%$ & 20 \\
\hline 4 & The degree of own revenues financing & 5 & $10.14 \%$ & 20 \\
\hline 5 & The self-financing degree & 3 & $120.50 \%$ & 100 \\
\hline
\end{tabular}




\begin{tabular}{|l|l|l|l|l|}
6 & The degree of property taxes collection & 5 & $53.04 \%$ & 60 \\
\hline 7 & $\begin{array}{l}\text { The dependence degree of the local budget to the state } \\
\text { budget }\end{array}$ & 5 & $31.10 \%$ & 40 \\
\hline 8 & The degree of decisional autonomy & 4 & $40.06 \%$ & 60 \\
\hline 9 & The rigidity of the expense & 5 & $72.48 \%$ & 40 \\
\hline 10 & The weight of the functioning section & 5 & $27.52 \%$ & 20 \\
\hline Aggregated note $=\mathbf{4 7 . 6 6}$ & \\
\hline
\end{tabular}

The Territorial Administrative Entity Ceru Băcăinţi

\begin{tabular}{|l|l|l|l|l|}
\hline $\begin{array}{c}\text { Ref. } \\
\text { no }\end{array}$ & \multicolumn{1}{|c|}{ Indicator } & $\begin{array}{c}\text { Coefficient } \\
\text { of } \\
\text { importance }\end{array}$ & $\begin{array}{c}\text { Calculate } \\
\text { value }\end{array}$ & \multicolumn{1}{|c|}{ Score } \\
\hline 1 & The degree of revenues achievement & 5 & $72.84 \%$ & 80 \\
\hline 2 & The degree of revenues collection & 5 & $62.52 \%$ & 60 \\
\hline 3 & The degree of own revenues collection & 5 & $37.11 \%$ & 20 \\
\hline 4 & The degree of own revenues financing & 5 & $11.07 \%$ & 20 \\
\hline 5 & The self-financing degree & 3 & $116.36 \%$ & 100 \\
\hline 6 & The degree of property taxes collection & 5 & $88.93 \%$ & 20 \\
\hline 7 & The dependence degree of the local budget to the state budget & 5 & $47.98 \%$ & 60 \\
\hline 8 & The degree of decisional autonomy & 4 & $76.17 \%$ & 40 \\
\hline 9 & The rigidity of the expense & 5 & $98.21 \%$ & 20 \\
\hline 10 & The weight of the functioning section & 5 & $1.79 \%$ & 20 \\
\hline & Aggregated note $=\mathbf{4 1 . 7 0}$ & & & \\
\hline
\end{tabular}

The Territorial Administrative Entity Horea

\begin{tabular}{|l|l|l|l|l|}
\hline $\begin{array}{c}\text { Ref. } \\
\text { no. }\end{array}$ & \multicolumn{1}{|c|}{ Indicator } & $\begin{array}{c}\text { Coefficient } \\
\text { of } \\
\text { importance }\end{array}$ & $\begin{array}{c}\text { Calculate } \\
\text { value }\end{array}$ & \multicolumn{1}{|c|}{ Score } \\
\hline 1 & The degree of revenues achievement & 5 & $55.95 \%$ & 60 \\
\hline 2 & The degree of revenues collection & 5 & $83.34 \%$ & 80 \\
\hline 3 & The degree of own revenues collection & 5 & $15.38 \%$ & 20 \\
\hline 4 & The degree of own revenues financing & 5 & $2.61 \%$ & 20 \\
\hline 5 & The self-financing degree & 3 & $76.48 \%$ & 80 \\
\hline 6 & The degree of property taxes collection & 5 & $97.39 \%$ & 20 \\
\hline 7 & The dependence degree of the local budget to the state budget & 5 & $20.52 \%$ & 20 \\
\hline 8 & The degree of decisional autonomy & 4 & $32.85 \%$ & 80 \\
\hline 9 & The rigidity of the expense & 5 & $47.55 \%$ & 60 \\
\hline 10 & The weight of the functioning section & 5 & $52.45 \%$ & 60 \\
\hline & Aggregated note= 48.08 & & & \\
\hline
\end{tabular}

After analysing the aggregated note, all three territorial administrative entities are inside the interval $40-60$, being considered public institutions with a good financial condition.

\section{Conclusions}


To the present time, the local communities are confronted with two important challenges acting in different directions: the globalisation and the decentralisation. Globalisation leads to an increased number of interactions between communities; most of the time, the interactions belong to the actors that are part of larger networks. The diagnosis is the preliminary stage of the strategic plan, providing all the reasoning necessary to the confrontation between the desires of the managerial team and the internal and external reality. It is an instrument in the service of the will to change and to progress, animating the powerful teams. The information is the premise for the optimisation of the managerial decision, when it reaches the quality exigence related to utility, accessibility, pertinence, fidelity, communicability, reactivity and coherence.

Using the presented model, we are able to establish the financial position of the territorial administrative entity. To test the proposed model, we intend to extend the research in the future to the Romanian territorial administrative entities classified on structures depending on various criteria.

\section{References}

1. Ammons, D. N., Coe, C., \& Lombardo, M., 2001, Performance-Comparison Projects in Local Government: Participants' Perspectives, Public Administration Review, 61(1), pp. 100-110.

2. Cabaleiro, R., Buch, E., \& Vaamonde, A., 2012, Developing a method to assessing the municipal financial health, The American Review of Public Administration, 0275074012451523. pp. 2-23.

3. Dougherty, M. J., Klase, K. A., \& Song, S. G., 2000, The relationships between public finance issues, financial management issues, and conditions of fiscal stress in small and rural governments: The case of West Virginia, Journal of Public Budgeting Accounting and Financial Management, 12, pp. 545-565.

4. Groves, S. M., Godsey, W. M., \& Shulman, M. A.,1981, Financial indicators for local government, Public Budgeting and Finance, 1(2), pp. 5-19.

5. Zafra Gómez, J.L., López Hernández, A.M. Și Hernández Bastida, A., 2009, Developing a Model to Measure Financial Condition in Local Governments, American Reviewof Public Administration, vol. 39, nr. 4, pp. 425-449.

6. Teodor Hada, 2010, Gestiunea financiară a întreprinderii, Ed. Aeternitas, Alba Iulia.

7. Kloha, P., Weissert, C. S., \& Kleine, R.. 2005, Developing and testing a composite model to predict local fiscal distress, Public Administration Review, 65(3), pp. 313-323.

8. Maria Niculescu, 2003, Diagnostic Economic, Ed. Economică, vol.1, București.

9. O.M.F.P. nr. 1177/2018 pentru aprobarea Normelor metodologice privind întocmirea şi depunerea situaţiilor financiare ale Instituţiilor publice la 31 decembrie 2017

10. Ordinului ministrului finanțelor publice nr. 1.917/2005 pentru aprobarea Normelor metodologice privind organizarea și conducerea contabilității instituțiilor publice. 


\section{Annex no. 1. BALANCE SHEET - Territorial administrative entity Pianu}

\begin{tabular}{|c|c|c|c|c|c|c|c|}
\hline \multicolumn{8}{|c|}{ BALANCE SHEET - Territorial administrative entity Pianu } \\
\hline \multicolumn{8}{|c|}{ 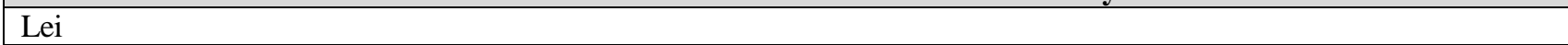 } \\
\hline $\begin{array}{l}\text { Ref. } \\
\text { no. }\end{array}$ & INDICATORS & $\begin{array}{l}\text { Row } \\
\text { code }\end{array}$ & 2013 & 2014 & 2015 & 2016 & 2017 \\
\hline 1. & ASSETS & 01 & $\mathrm{X}$ & $\mathrm{X}$ & $\mathrm{X}$ & $\mathrm{X}$ & $\mathrm{X}$ \\
\hline 2. & NON-CURRENT ASSETS & 02 & $\mathrm{X}$ & $\mathrm{X}$ & $\mathrm{X}$ & $\mathrm{X}$ & $\mathrm{X}$ \\
\hline 3. & Intangible fixed assets & 03 & 198994 & 250008 & 487751 & 329767 & 329351 \\
\hline 4. & $\begin{array}{l}\text { Technical installations, transport means, } \\
\text { animals, plantations, furniture, office } \\
\text { equipment and other tangible assets }\end{array}$ & 04 & 382500 & 783060 & 766955 & 755935 & 629909 \\
\hline 5. & Land and buildings & 05 & 30132283 & 31787600 & 33684974 & 45076699 & 47027255 \\
\hline 6. & Other non-financial assets & 06 & & & & & \\
\hline 7. & $\begin{array}{l}\text { Non-current financial assets (long term } \\
\text { investments), over an year, among which: }\end{array}$ & 07 & & & & & \\
\hline 8. & Shareholdings & 08 & & & & & \\
\hline 9. & $\begin{array}{l}\text { Non-current entitlements }- \text { sums to be } \\
\text { collected for a period longer than one } \\
\text { year, among which: }\end{array}$ & 09 & & & & & \\
\hline 10. & $\begin{array}{l}\text { Non-current commercial entitlements - } \\
\text { sums to be collected after a period longer } \\
\text { than one year }\end{array}$ & 10 & & & & & \\
\hline 11. & TOTAL NON-CURRENT ASSETS & 15 & 30713777 & 32820668 & 34969680 & 46162401 & 47986515 \\
\hline 12. & CURRENT ASSETS & 18 & $\mathrm{X}$ & $\mathrm{x}$ & $\mathrm{x}$ & $\mathrm{x}$ & $\mathrm{x}$ \\
\hline 13. & Stocks & 19 & 484445 & 478899 & 683315 & 795337 & 868569 \\
\hline 14. & $\begin{array}{l}\text { Current entitlements }- \text { sums to be } \\
\text { collected in a period shorter than one year }\end{array}$ & 20 & $\mathrm{X}$ & $\mathrm{x}$ & $\mathrm{x}$ & $\mathrm{x}$ & $\mathrm{x}$ \\
\hline 15. & $\begin{array}{l}\text { Entitlements from commercial operations, } \\
\text { payments on account and settlements, } \\
\text { among which }\end{array}$ & 21 & 4479 & 3432 & 4359 & 8806 & 39454 \\
\hline 16. & $\begin{array}{l}\text { Settlements on current state budgetary } \\
\text { execution }\end{array}$ & 21.1 & & & & & \\
\hline 17. & $\begin{array}{l}\text { Commercial entitlements and payments } \\
\text { on account, among which: }\end{array}$ & 22 & 4479 & 3432 & 4359 & 8806 & 39454 \\
\hline 18. & Advances & 22.1 & & & & & \\
\hline 19. & Budgetary entitlements, among which: & 23 & 323040 & 747083 & 703130 & 1030687 & 1066298 \\
\hline 20. & $\begin{array}{l}\text { Entitlements from the consolidated } \\
\text { general budget }\end{array}$ & 24 & 323040 & 747083 & 703130 & 1030687 & 1066298 \\
\hline 21. & $\begin{array}{l}\text { Entitlements from transactions } \\
\text { external non-refundable funds } \\
\text { budgetary funds, among which: }\end{array}$ & 25 & 269011 & & & & \\
\hline 22. & $\begin{array}{l}\text { Sums to be received from the European } \\
\text { Commission/ other donors }\end{array}$ & 26 & & & & & \\
\hline 23. & Loans granted on short-term & 27 & & & & & \\
\hline 24. & Total current entitlements & 30 & 596530 & 750515 & 707489 & 1039493 & 1105752 \\
\hline 25. & Short-term investments & 31 & & & & & \\
\hline 26. & $\begin{array}{l}\text { Treasury accounts and account to credit } \\
\text { institutions: }\end{array}$ & 32 & $\mathrm{X}$ & $\mathrm{x}$ & $\mathrm{x}$ & $\mathrm{x}$ & $\mathrm{x}$ \\
\hline 27. & Treasury accounts, RON register & 33 & 771336 & 818842 & 520553 & 733285 & 3182706 \\
\hline 28. & $\begin{array}{l}\text { Interests to be collected, other values, } \\
\text { treasury payments on account }\end{array}$ & 33.1 & & & & & \\
\hline 29. & Deposits & 34 & $\mathrm{X}$ & $\mathrm{x}$ & $\mathrm{x}$ & $\mathrm{x}$ & $\mathrm{x}$ \\
\hline 30. & $\begin{array}{l}\text { Account to credit institutions, National } \\
\text { Bank of Romania, foreign currency } \\
\text { register }\end{array}$ & 35 & & & & & \\
\hline 31. & $\begin{array}{l}\text { Interests to be collected, other values, } \\
\text { treasury payments on account }\end{array}$ & 35.1 & & & & & \\
\hline
\end{tabular}




\begin{tabular}{|c|c|c|c|c|c|c|c|}
\hline 32. & Deposits & 36 & $\mathrm{X}$ & $\bar{X}$ & $\bar{X}$ & $\bar{X}$ & $\mathrm{X}$ \\
\hline 33. & Total availabilities and other values & 40 & 771336 & 818842 & 520553 & 733285 & 3182706 \\
\hline 34. & $\begin{array}{l}\text { Availabilities accounts of the Central } \\
\text { Treasury and of the territorial treasuries }\end{array}$ & 41 & & & & & \\
\hline 35. & $\begin{array}{l}\text { Interests to be collected, other values, } \\
\text { treasury payments on account }\end{array}$ & 41.1 & & & & & \\
\hline 36. & Prepayments & 42 & & & & & \\
\hline 37. & TOTAL CURRENT ASSETS & 45 & 1852311 & 2048256 & 1911357 & 2568115 & 5157027 \\
\hline 38. & TOTAL ASSETS & 46 & 32566088 & 34838924 & 36851037 & 48730516 & 53143542 \\
\hline 39. & LIABILITIES & 50 & $\mathrm{X}$ & $\mathrm{x}$ & $\mathrm{x}$ & $\mathrm{x}$ & $\mathrm{x}$ \\
\hline 40. & $\begin{array}{l}\text { NON-CURRENT LIABILITIES- sums to } \\
\text { be paid after a period longer than one year }\end{array}$ & 51 & $\mathrm{X}$ & $\mathrm{x}$ & $\mathrm{x}$ & $\mathrm{x}$ & $\mathrm{x}$ \\
\hline 41. & $\begin{array}{l}\text { Non-current sums - sums to be paid after } \\
\text { a period longer than one year, among } \\
\text { which: }\end{array}$ & 52 & & & & & \\
\hline 42. & Commercial liabilities & 53 & & & & & \\
\hline 43. & Long-term loans & 54 & & & & & \\
\hline 44. & Provisions & 55 & 216,310 & 216310 & 216310 & 165376 & 165376 \\
\hline 45. & TOTAL NON-CURRENT LIABILITIES & 58 & 216310 & 216310 & 165376 & 165376 & 165376 \\
\hline 46. & $\begin{array}{l}\text { CURRENT LIABILITIES - sums to be } \\
\text { paid in a period shorter than one year }\end{array}$ & 59 & $\mathrm{X}$ & $\mathrm{x}$ & $\mathrm{x}$ & $\mathrm{x}$ & $\mathrm{x}$ \\
\hline 47. & $\begin{array}{l}\text { Commercial liabilities, payments on } \\
\text { account and other settlements, among } \\
\text { which: }\end{array}$ & 60 & 57969 & 38625 & 344363 & 60430 & 47895 \\
\hline 48. & $\begin{array}{l}\text { Settlements related to the state budgetary } \\
\text { execution for the current year }\end{array}$ & 60.1 & & & 2912 & 5984 & 5438 \\
\hline 49. & $\begin{array}{l}\text { Commercial liabilities and payments on } \\
\text { account, among which: }\end{array}$ & 61 & 57969 & 35970 & 341451 & 54445 & 42457 \\
\hline 50. & Received payments on account & 61.1 & & & & & \\
\hline 51. & Liabilities to budgets, among which: & 62 & 58982 & 52214 & 71884 & 98675 & 104507 \\
\hline 52. & $\begin{array}{l}\text { Liabilities of the public institutions to the } \\
\text { budgets }\end{array}$ & 63 & $\mathrm{X}$ & $\mathrm{x}$ & $\mathrm{x}$ & $\mathrm{x}$ & $\mathrm{x}$ \\
\hline 53. & Social security contributions & 63.1 & 42854 & 36581 & 49366 & 65007 & 61341 \\
\hline 54. & $\begin{array}{l}\text { Sums from external non-refundable } \\
\text { Funds owed to the budget }\end{array}$ & 64 & & & & & \\
\hline 55. & $\begin{array}{l}\text { Liabilities from transactions with external } \\
\text { non-refundable Funds and budgetary } \\
\text { funds, other liabilities to other } \\
\text { international entities, among which: }\end{array}$ & 65 & 130353 & & & & 3342469 \\
\hline 56. & $\begin{array}{l}\text { Sums owed to the European Commission/ } \\
\text { other donors }\end{array}$ & 66 & & & & & \\
\hline 57. & $\begin{array}{l}\text { Short-term loans - sums to be paid in a } \\
\text { period shorter than one year }\end{array}$ & 70 & & & & & \\
\hline 58. & $\begin{array}{l}\text { Long-term loans - sums to be paid during } \\
\text { the current financial year }\end{array}$ & 71 & & & & & \\
\hline 59. & Staff wages & 72 & 74372 & 75222 & 98461 & 139323 & 181956 \\
\hline 60. & $\begin{array}{l}\text { Other entitlements for various categories } \\
\text { (pensions, unemployment benefits, } \\
\text { grants), among which: }\end{array}$ & 73 & & & & & \\
\hline 61. & Pensions, unemployment benefits, grants & 73.1 & $\mathrm{X}$ & $\mathrm{x}$ & $\mathrm{x}$ & $\mathrm{x}$ & $\mathrm{x}$ \\
\hline 62. & Accruals & 74 & & & & & \\
\hline 63. & Provisions & 75 & & & & & \\
\hline 64. & TOTAL CURRENT LIABILITIES & 78 & 321676 & 166061 & 514708 & 298428 & 3676827 \\
\hline 65. & TOTAL LIABILITIES & 79 & 537986 & 382371 & 680084 & 463804 & 3842203 \\
\hline 66. & $\begin{array}{l}\text { NET ASSETS }=\text { TOTAL ASSETS }- \\
\text { TOTAL LIABILITIES = EQUITY } \\
\text { INSTRUMENTS }\end{array}$ & 80 & 32028102 & 34486553 & 36170953 & 48266712 & 49301339 \\
\hline 67. & EQUITY INSTRUMENTS & 83 & $\mathrm{X}$ & $\mathrm{x}$ & $\mathrm{x}$ & $\mathrm{x}$ & $\mathrm{x}$ \\
\hline 68. & Reserves, funds & 84 & 29484042 & 29484042 & 29477667 & 44208372 & 44208372 \\
\hline
\end{tabular}




\begin{tabular}{|l|l|l|l|l|l|l|l|}
\hline 69. & Reported outturn & 85 & 3597436 & $2,528,967$ & $5,011,541$ & $6,794,142$ & $4,031,676$ \\
\hline 70. & Reported outturn & 86 & & & & & \\
\hline 71. & Economic outturn of the financial year & 87 & & 2473544 & 1681745 & & 1061291 \\
\hline 72. & Economic outturn of the financial year & 88 & 1053376 & & & 2735802 & \\
\hline 73. & TOTAL EQUITY INSTRUMENTS & 90 & 32028102 & 34486553 & 36170953 & 48266712 & 49301339 \\
\hline
\end{tabular}

Annex no. 2. BALANCE SHEET - Territorial administrative entity Horea

\begin{tabular}{|c|c|c|c|c|c|c|c|}
\hline \multicolumn{8}{|c|}{ BALANCE SHEET - Territorial administrative entity Horea } \\
\hline \multicolumn{8}{|c|}{ 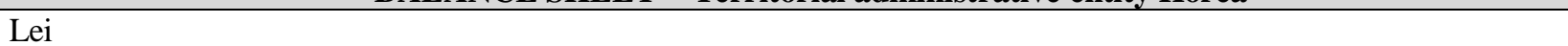 } \\
\hline $\begin{array}{l}\text { Ref. } \\
\text { no. }\end{array}$ & INDICATORS & $\begin{array}{l}\text { Row } \\
\text { code }\end{array}$ & 2013 & 2014 & 2015 & 2016 & 2017 \\
\hline 1. & ASSETS & 01 & $\mathrm{X}$ & $\mathrm{X}$ & $\mathrm{X}$ & $\mathrm{X}$ & $\mathrm{X}$ \\
\hline 2. & NON-CURRENT ASSETS & 02 & $\mathrm{X}$ & $\mathrm{X}$ & $\mathrm{X}$ & $\mathrm{X}$ & $\mathrm{X}$ \\
\hline 3. & Intangible fixed assets & 03 & 1500 & 1500 & 17620 & 48220 & 42100 \\
\hline 4. & $\begin{array}{l}\text { Technical installations, } \\
\text { transport means, animals, } \\
\text { plantations, furniture, } \\
\text { office equipment and other } \\
\text { tangible assets }\end{array}$ & 04 & 184345 & 235030 & 309880 & 287622 & 509808 \\
\hline 5. & Land and buildings & 05 & 36951532 & 42082092 & 61472416 & 50890861 & 63271396 \\
\hline 6. & Other non-financial assets & 06 & & & & & \\
\hline 7. & $\begin{array}{lr}\text { Non-current } & \text { financial } \\
\text { assets (long term } \\
\text { investments), over an year, } \\
\text { among which: }\end{array}$ & 07 & & & & & \\
\hline 8. & Shareholdings & 08 & & & & & \\
\hline 9. & $\begin{array}{l}\text { Non-current entitlements - } \\
\text { sums to be collected for a } \\
\text { period longer than one } \\
\text { year, among which: }\end{array}$ & 09 & & & & & \\
\hline 10. & $\begin{array}{l}\text { Non-current commercial } \\
\text { entitlements - sums to be } \\
\text { collected after a period } \\
\text { longer than one year }\end{array}$ & 10 & & & & & \\
\hline 11. & $\begin{array}{l}\text { TOTAL NON-CURRENT } \\
\text { ASSETS }\end{array}$ & 15 & 37137377 & 42318622 & 61799916 & 51226703 & 63823304 \\
\hline 12. & CURRENT ASSETS & 18 & $\mathrm{X}$ & $\mathrm{x}$ & $\mathrm{x}$ & $\mathrm{x}$ & $\mathrm{x}$ \\
\hline 13. & Stocks & 19 & 115114 & 125414 & 223359 & 209349 & 208988 \\
\hline 14. & $\begin{array}{l}\text { Current entitlements - } \\
\text { sums to be collected in a } \\
\text { period shorter than one } \\
\text { year }\end{array}$ & 20 & $\mathrm{x}$ & $\mathrm{x}$ & $\mathrm{x}$ & $\mathrm{x}$ & $\mathrm{x}$ \\
\hline 15. & $\begin{array}{l}\text { Entitlements from } \\
\text { commercial operations, } \\
\text { payments on account and } \\
\text { settlements, among which }\end{array}$ & 21 & 4938 & 27097 & 13622 & 12798 & 15768 \\
\hline 16. & $\begin{array}{l}\text { Settlements on current state } \\
\text { budgetary execution }\end{array}$ & 21.1 & & & & & \\
\hline 17. & $\begin{array}{l}\text { Commercial entitlements } \\
\text { and payments on account, } \\
\text { among which: }\end{array}$ & 22 & 4938 & 27097 & 13622 & 12798 & 15768 \\
\hline 18. & Advances & 22.1 & & & & & \\
\hline 19. & $\begin{array}{l}\text { Budgetary entitlements, } \\
\text { among which: }\end{array}$ & 23 & 104634 & 130244 & 168342 & 169151 & 214165 \\
\hline 20. & $\begin{array}{lr}\begin{array}{l}\text { Entitlements } \\
\text { consolidated } \\
\text { budget }\end{array} & \text { from the } \\
\text { general }\end{array}$ & 24 & 104634 & 130244 & 168342 & 169151 & 214165 \\
\hline
\end{tabular}




\begin{tabular}{|c|c|c|c|c|c|c|c|}
\hline 21. & $\begin{array}{l}\text { Entitlements } \\
\text { transactions with external } \\
\text { non-refundable funds and } \\
\text { budgetary funds, among } \\
\text { which: }\end{array}$ & 25 & & & & & \\
\hline 22. & $\begin{array}{l}\text { Sums to be received from } \\
\text { the European Commission/ } \\
\text { other donors }\end{array}$ & 26 & & & & & \\
\hline 23. & $\begin{array}{l}\text { Loans granted on short- } \\
\text { term }\end{array}$ & 27 & & & & & \\
\hline 24. & Total current entitlements & 30 & 109572 & 157341 & 181964 & 181949 & 229933 \\
\hline 25. & Short-term investments & 31 & & & & & \\
\hline 26. & $\begin{array}{lcr}\text { Treasury accounts } & \text { and } \\
\text { account to } & \text { credit } \\
\text { institutions: } & & \end{array}$ & 32 & $\mathrm{X}$ & $\mathrm{x}$ & $\mathrm{x}$ & $\mathrm{x}$ & $\mathrm{x}$ \\
\hline 27. & $\begin{array}{l}\text { Treasury accounts, RON } \\
\text { register }\end{array}$ & 33 & 2310179 & 1200170 & 1599981 & 2008191 & 973306 \\
\hline 28. & $\begin{array}{l}\text { Interests to be collected, } \\
\text { other values, treasury } \\
\text { payments on account }\end{array}$ & 33.1 & & & & & \\
\hline 29. & Deposits & 34 & $\mathrm{X}$ & $\mathrm{x}$ & $\mathrm{x}$ & $\mathrm{x}$ & $\mathrm{x}$ \\
\hline 30. & $\begin{array}{l}\text { Account to } r \text { credit } \\
\text { institutions, National Bank } \\
\text { of Romania, foreign } \\
\text { currency register }\end{array}$ & 35 & & & & & \\
\hline 31. & $\begin{array}{l}\text { Interests to be collected, } \\
\text { other values, treasury } \\
\text { payments on account }\end{array}$ & 35.1 & & & & & \\
\hline 32. & Deposits & 36 & $\mathrm{X}$ & $\mathrm{X}$ & $\mathrm{X}$ & $\mathrm{X}$ & $\mathrm{X}$ \\
\hline 33. & $\begin{array}{l}\text { Total availabilities and } \\
\text { other values }\end{array}$ & 40 & 2310179 & 1200170 & 1599981 & 2008191 & 973306 \\
\hline 34. & $\begin{array}{l}\text { Availabilities accounts of } \\
\text { the Central Treasury and of } \\
\text { the territorial treasuries }\end{array}$ & 41 & & & & & \\
\hline 35. & $\begin{array}{l}\text { Interests to be collected, } \\
\text { other values, treasury } \\
\text { payments on account }\end{array}$ & 41.1 & & & & & \\
\hline 36. & Prepayments & 42 & & & & & \\
\hline 37. & $\begin{array}{ll}\text { TOTAL } & \text { CURRENT } \\
\text { ASSETS } & \\
\end{array}$ & 45 & 2534865 & 1482925 & 2005304 & 2399489 & 1412227 \\
\hline 38. & TOTAL ASSETS & 46 & 39672242 & 43801547 & 63805220 & 53626192 & 65235531 \\
\hline 39. & LIABILITIES & 50 & $\mathrm{X}$ & $\mathrm{x}$ & $\mathrm{x}$ & $\mathrm{x}$ & $\mathrm{x}$ \\
\hline 40. & $\begin{array}{l}\text { NON-CURRENT } \\
\text { LIABILITIES- sums to be } \\
\text { paid after a period longer } \\
\text { than one year }\end{array}$ & 51 & $\mathrm{X}$ & $\mathrm{x}$ & $\mathrm{x}$ & $\mathrm{x}$ & $\mathrm{x}$ \\
\hline 41. & $\begin{array}{l}\text { Non-current sums - sums to } \\
\text { be paid after a period } \\
\text { longer than one year, } \\
\text { among which: }\end{array}$ & 52 & & & & & \\
\hline 42. & Commercial liabilities & 53 & & & & & \\
\hline 43. & Long-term loans & 54 & & & & & \\
\hline 44. & Provisions & 55 & 124,975 & 46975 & 46975 & 46975 & 46975 \\
\hline 45. & $\begin{array}{l}\text { TOTAL NON-CURRENT } \\
\text { LIABILITIES }\end{array}$ & 58 & 124975 & 46975 & 46975 & 46975 & 46975 \\
\hline 46. & $\begin{array}{l}\text { CURRENT LIABILITIES } \\
\text { - sums to be paid in a } \\
\text { period shorter than one } \\
\text { year }\end{array}$ & 59 & $\mathrm{X}$ & $\mathrm{x}$ & $\mathrm{x}$ & $\mathrm{x}$ & $\mathrm{x}$ \\
\hline
\end{tabular}




\begin{tabular}{|c|c|c|c|c|c|c|c|}
\hline 47. & $\begin{array}{l}\text { Commercial liabilities, } \\
\text { payments on account and } \\
\text { other settlements, among } \\
\text { which: }\end{array}$ & 60 & 12740 & 15250 & 15621 & 15127 & 12240 \\
\hline 48. & $\begin{array}{l}\text { Settlements related to the } \\
\text { state budgetary execution } \\
\text { for the current year }\end{array}$ & 60.1 & & & 3381 & 2887 & \\
\hline 49. & $\begin{array}{l}\text { Commercial liabilities and } \\
\text { payments on account, } \\
\text { among which: }\end{array}$ & 61 & 12740 & 12240 & 12240 & 12240 & 12240 \\
\hline 50. & $\begin{array}{lll}\begin{array}{l}\text { Received payments } \\
\text { account }\end{array} & \text { on } \\
\end{array}$ & 61.1 & & & & & \\
\hline 51. & $\begin{array}{l}\text { Liabilities to budgets, } \\
\text { among which: }\end{array}$ & 62 & 61919 & 282689 & 297971 & 300405 & 318540 \\
\hline 52. & $\begin{array}{l}\text { Liabilities of the public } \\
\text { institutions to the budgets }\end{array}$ & 63 & $\mathrm{X}$ & $\mathrm{x}$ & $\mathrm{x}$ & $\mathrm{x}$ & $\mathrm{x}$ \\
\hline 53. & $\begin{array}{ll}\begin{array}{l}\text { Social } \\
\text { contributions }\end{array} & \text { security } \\
\end{array}$ & 63.1 & 45291 & 36209 & 57073 & 62172 & 45103 \\
\hline 54. & $\begin{array}{l}\text { Sums from external non- } \\
\text { refundable Funds owed to } \\
\text { the budget }\end{array}$ & 64 & & & & & \\
\hline 55. & $\begin{array}{lr}\text { Liabilities } & \text { from } \\
\text { transactions with external } \\
\text { non-refundable Funds and } \\
\text { budgetary funds, other } \\
\text { liabilities to } \text { other } \\
\text { international entities, } \\
\text { among which: }\end{array}$ & 65 & & & & & \\
\hline 56. & $\begin{array}{l}\text { Sums owed to the } \\
\text { European Commission/ } \\
\text { other donors }\end{array}$ & 66 & & & & & \\
\hline 57. & $\begin{array}{l}\text { Short-term loans - sums to } \\
\text { be paid in a period shorter } \\
\text { than one year }\end{array}$ & 70 & & & & & \\
\hline 58. & $\begin{array}{l}\text { Long-term loans }- \text { sums to } \\
\text { be paid during the current } \\
\text { financial year }\end{array}$ & 71 & & & & & \\
\hline 59. & Staff wages & 72 & 46440 & 89813 & 111047 & 85836 & 148853 \\
\hline 60. & $\begin{array}{lr}\text { Other entitlements for } \\
\text { various r categories } \\
\text { (pensions, unemployment } \\
\text { benefits, grants), among } \\
\text { which: }\end{array}$ & 73 & & & & & \\
\hline 61. & $\begin{array}{l}\text { Pensions, unemployment } \\
\text { benefits, grants }\end{array}$ & 73.1 & $\mathrm{x}$ & $\mathrm{x}$ & $\mathrm{x}$ & $\mathrm{x}$ & $\mathrm{x}$ \\
\hline 62. & Accruals & 74 & & & & & \\
\hline 63. & Provisions & 75 & & & & & \\
\hline 64. & $\begin{array}{ll}\text { TOTAL } & \text { CURRENT } \\
\text { LIABILITIES } & \end{array}$ & 78 & 121099 & 387752 & 424639 & 401368 & 479633 \\
\hline 65. & TOTAL LIABILITIES & 79 & 246074 & 434727 & 471614 & 448343 & 526608 \\
\hline 66. & $\begin{array}{l}\text { NET ASSETS = TOTAL } \\
\text { ASSETS - TOTAL } \\
\text { LIABILITIES = EQUITY } \\
\text { INSTRUMENTS }\end{array}$ & 80 & 39426168 & 43366820 & 63333606 & 53177849 & 64708923 \\
\hline 67. & EQUITY INSTRUMENTS & 83 & $\mathrm{x}$ & $\mathrm{x}$ & $\mathrm{x}$ & $\mathrm{x}$ & $\mathrm{x}$ \\
\hline 68. & Reserves, funds & 84 & 25782120 & 33484336 & 53074319 & 44492071 & 44492071 \\
\hline 69. & Reported outturn & 85 & 11684468 & & 227,150 & $10,203,671$ & $16,294,943$ \\
\hline 70. & Reported outturn & 86 & & 4267867 & & & \\
\hline 71. & Economic outturn of the & 87 & 1959580 & & & & 3921909 \\
\hline
\end{tabular}




\begin{tabular}{|l|l|l|l|l|l|l|l|}
\hline & financial year & & & & & & \\
\hline 72. & $\begin{array}{l}\text { Economic outturn of the } \\
\text { financial year }\end{array}$ & & 4267867 & & 1517893 & \\
\hline 73. & $\begin{array}{l}\text { TOTAL EQUTTY } \\
\text { INSTRUMENTS }\end{array}$ & 90 & 39426168 & 43366820 & 63333606 & 53177849 & 64708923 \\
\hline
\end{tabular}

Annex no. 3. BALANCE SHEET - Territorial administrative entity Ceru Băcăinţi

\begin{tabular}{|c|c|c|c|c|c|c|c|}
\hline \multicolumn{8}{|c|}{ BALANCE SHEET - Territorial administrative entity Ceru Băcăinţi } \\
\hline \multicolumn{8}{|c|}{ e } \\
\hline $\begin{array}{l}\text { Ref. } \\
\text { no. }\end{array}$ & INDICATORS & $\begin{array}{l}\text { Row } \\
\text { Code }\end{array}$ & 2013 & 2014 & 2015 & 2016 & 2017 \\
\hline 1. & ASSETS & 01 & $\mathrm{X}$ & $\mathrm{X}$ & $\mathrm{X}$ & $\mathrm{X}$ & $\mathrm{X}$ \\
\hline 2. & NON-CURRENT ASSETS & 02 & $\mathrm{X}$ & $\mathrm{X}$ & $\mathrm{X}$ & $\mathrm{X}$ & $\mathrm{X}$ \\
\hline 3. & Intangible fixed assets & 03 & 15199 & 15199 & 155359 & 134119 & 118879 \\
\hline 4. & $\begin{array}{l}\text { Technical installations, transport } \\
\text { means, animals, plantations, } \\
\text { furniture, office equipment and } \\
\text { other tangible assets }\end{array}$ & 04 & 5610 & 116094 & 135072 & 13453 & 6656 \\
\hline 5. & Land and buildings & 05 & 3469812 & 3416523 & 10254041 & 10254041 & 10271107 \\
\hline 6. & Other non-financial assets & 06 & & & & & \\
\hline 7. & $\begin{array}{l}\text { Non-current financial assets } \\
\text { (long term investments), over an } \\
\text { year, among which: }\end{array}$ & 07 & & & & & \\
\hline 8. & Shareholdings & 08 & & & & & \\
\hline 9. & $\begin{array}{l}\text { Non-current entitlements - sums } \\
\text { to be collected for a period } \\
\text { longer than one year, among } \\
\text { which: }\end{array}$ & 09 & & & & & \\
\hline 10. & $\begin{array}{l}\text { Non-current } \\
\text { entitlements }- \text { commercial } \\
\text { collected after a period lo be } \\
\text { than one year }\end{array}$ & 10 & & & & & \\
\hline 11. & $\begin{array}{ll}\text { TOTAL } & \text { NON-CURRENT } \\
\text { ASSETS } & \end{array}$ & 15 & 3490621 & 3547816 & 10544472 & 10401613 & 10396642 \\
\hline 12. & CURRENT ASSETS & 18 & $\mathrm{x}$ & $\mathrm{X}$ & $\mathrm{x}$ & $\mathrm{x}$ & $\mathrm{x}$ \\
\hline 13. & Stocks & 19 & 69512 & 69512 & 74423 & 72364 & 90588 \\
\hline 14. & $\begin{array}{l}\text { Current entitlements }- \text { sums to } \\
\text { be collected in a period shorter } \\
\text { than one year }\end{array}$ & 20 & $\mathrm{x}$ & $\mathrm{X}$ & $\mathrm{x}$ & $\mathrm{x}$ & $\mathrm{x}$ \\
\hline 15. & $\begin{array}{l}\text { Entitlements from commercial } \\
\text { operations, payments on account } \\
\text { and settlements, among which }\end{array}$ & 21 & 3439 & 58224 & 55830 & 53289 & 53289 \\
\hline 16. & $\begin{array}{l}\text { Settlements on current state } \\
\text { budgetary execution }\end{array}$ & 21.1 & & & & & \\
\hline 17. & $\begin{array}{l}\text { Commercial entitlements and } \\
\text { payments on account, among } \\
\text { which: }\end{array}$ & 22 & 3439 & 58224 & 55830 & 53289 & 53289 \\
\hline 18. & Advances & 22.1 & & & & & \\
\hline 19. & $\begin{array}{l}\text { Budgetary entitlements, among } \\
\text { which: }\end{array}$ & 23 & 39649 & 84020 & 83845 & 91713 & 95121 \\
\hline 20. & $\begin{array}{l}\text { Entitlements from the } \\
\text { consolidated general budget }\end{array}$ & 24 & 33790 & 84020 & 83845 & 91713 & 95121 \\
\hline 21. & $\begin{array}{l}\text { Entitlements from transactions } \\
\text { with external non-refundable } \\
\text { funds and budgetary funds, } \\
\text { among which: }\end{array}$ & 25 & & & & & \\
\hline 22. & Sums to be received from the & 26 & & & & & \\
\hline
\end{tabular}




\begin{tabular}{|c|c|c|c|c|c|c|c|}
\hline & $\begin{array}{l}\text { European Commission/ other } \\
\text { donors }\end{array}$ & & & & & & \\
\hline 23. & Loans granted on short-term & 27 & & & & & \\
\hline 24. & Total current entitlements & 30 & 43088 & 142244 & 139675 & 145002 & 148410 \\
\hline 25. & Short-term investments & 31 & & & & & \\
\hline 26. & $\begin{array}{l}\text { Treasury accounts and account } \\
\text { to credit institutions: }\end{array}$ & 32 & $\mathrm{x}$ & $\mathrm{X}$ & $\mathrm{x}$ & $\mathrm{x}$ & $\mathrm{x}$ \\
\hline 27. & Treasury accounts, RON register & 33 & 1608 & 2300978 & 48061 & 45488 & 1390 \\
\hline 28. & $\begin{array}{l}\text { Interests to be collected, other } \\
\text { values, treasury payments on } \\
\text { account }\end{array}$ & 33.1 & & & & & \\
\hline 29. & Deposits & 34 & $\mathrm{x}$ & $\mathrm{X}$ & $\mathrm{x}$ & $\mathrm{x}$ & $\mathrm{x}$ \\
\hline 30. & $\begin{array}{l}\text { Account to credit institutions, } \\
\text { National Bank of Romania, } \\
\text { foreign currency register }\end{array}$ & 35 & & & & & \\
\hline 31. & $\begin{array}{l}\text { Interests to be collected, other } \\
\text { values, treasury payments on } \\
\text { account }\end{array}$ & 35.1 & & & & & \\
\hline 32. & Deposits & 36 & $\mathrm{X}$ & $\mathrm{X}$ & $\mathrm{X}$ & $\mathrm{X}$ & $\mathrm{X}$ \\
\hline 33. & $\begin{array}{l}\text { Total availabilities and other } \\
\text { values }\end{array}$ & 40 & 1608 & 2300978 & 48061 & 45488 & 1390 \\
\hline 34. & $\begin{array}{l}\text { Availabilities accounts of the } \\
\text { Central Treasury and of the } \\
\text { territorial treasuries }\end{array}$ & 41 & & & & & \\
\hline 35. & $\begin{array}{l}\text { Interests to be collected, other } \\
\text { values, treasury payments on } \\
\text { account }\end{array}$ & 41.1 & & & & & \\
\hline 36. & Prepayments & 42 & & & & & \\
\hline 37. & TOTAL CURRENT ASSETS & 45 & 114208 & 2512734 & 262159 & 262854 & 240388 \\
\hline 38. & TOTAL ASSETS & 46 & 3604829 & 6060550 & 10806631 & 10664467 & 10637030 \\
\hline 39. & LIABILITIES & 50 & $\mathrm{x}$ & $\mathrm{X}$ & $\mathrm{x}$ & $\mathrm{x}$ & $\mathrm{x}$ \\
\hline 40. & $\begin{array}{l}\text { NON-CURRENT } \\
\text { LIABILITIES- sums to be paid } \\
\text { after a period longer than one } \\
\text { year }\end{array}$ & 51 & $\mathrm{x}$ & $\mathrm{X}$ & $\mathrm{x}$ & $\mathrm{x}$ & $\mathrm{x}$ \\
\hline 41. & $\begin{array}{l}\text { Non-current sums - sums to be } \\
\text { paid after a period longer than } \\
\text { one year, among which: }\end{array}$ & 52 & & & & & \\
\hline 42. & Commercial liabilities & 53 & & & & & \\
\hline 43. & Long-term loans & 54 & & & & & \\
\hline 44. & Provisions & 55 & 43,810 & 37810 & 24405 & 24405 & \\
\hline 45. & $\begin{array}{l}\text { TOTAL NON-CURRENT } \\
\text { LIABILITIES }\end{array}$ & 58 & 43810 & 37810 & 24405 & 24405 & \\
\hline 46. & $\begin{array}{l}\text { CURRENT LIABILITIES - } \\
\text { sums to be paid in a period } \\
\text { shorter than one year }\end{array}$ & 59 & $\mathrm{x}$ & $\mathrm{X}$ & $\mathrm{x}$ & $\mathrm{x}$ & $\mathrm{x}$ \\
\hline 47. & $\begin{array}{l}\text { Commercial liabilities, payments } \\
\text { on account and other } \\
\text { settlements, among which: }\end{array}$ & 60 & 4426 & 28914 & 25214 & 37199 & 34658 \\
\hline 48. & $\begin{array}{l}\text { Settlements related to the state } \\
\text { budgetary execution for the } \\
\text { current year }\end{array}$ & 60.1 & & & & & \\
\hline 49. & $\begin{array}{l}\text { Commercial liabilities and } \\
\text { payments on account, among } \\
\text { which: }\end{array}$ & 61 & 4426 & 28634 & 25214 & 37199 & 34658 \\
\hline 50. & Received payments on account & 61.1 & & & & & \\
\hline 51. & $\begin{array}{l}\text { Liabilities to budgets, among } \\
\text { which: }\end{array}$ & 62 & 10508 & 15092 & 14506 & 20774 & 24987 \\
\hline 52. & Liabilities of the public & 63 & $\mathrm{x}$ & $\mathrm{X}$ & $\mathrm{x}$ & $\mathrm{x}$ & $\mathrm{x}$ \\
\hline
\end{tabular}




\begin{tabular}{|c|c|c|c|c|c|c|c|}
\hline & institutions to the budgets & & & & & & \\
\hline 53. & Social security contributions & 63.1 & 7777 & 11923 & 10260 & 16238 & 18839 \\
\hline 54. & $\begin{array}{l}\text { Sums from external non- } \\
\text { refundable Funds owed to the } \\
\text { budget }\end{array}$ & 64 & & & & & \\
\hline 55. & $\begin{array}{l}\text { Liabilities from transactions } \\
\text { with external non-refundable } \\
\text { Funds and budgetary funds, } \\
\text { other liabilities to other } \\
\text { international entities, among } \\
\text { which: }\end{array}$ & 65 & & 2300000 & & & \\
\hline 56. & $\begin{array}{l}\text { Sums owed to the European } \\
\text { Commission/ other donors }\end{array}$ & 66 & & & & & \\
\hline 57. & $\begin{array}{l}\text { Short-term loans - sums to be } \\
\text { paid in a period shorter than one } \\
\text { year }\end{array}$ & 70 & & & & & \\
\hline 58. & $\begin{array}{l}\text { Long-term loans }- \text { sums to be } \\
\text { paid during the current financial } \\
\text { year }\end{array}$ & 71 & & & & & \\
\hline 59. & Staff wages & 72 & 58285 & 21460 & 27479 & 30250 & 73758 \\
\hline 60. & $\begin{array}{l}\text { Other entitlements for various } \\
\text { categories } \\
\text { unemployment benefits, grants), } \\
\text { among which: }\end{array}$ & 73 & & & & & \\
\hline 61. & $\begin{array}{ll}\text { Pensions, } & \text { unemployment } \\
\text { benefits, grants }\end{array}$ & 73.1 & $\mathrm{x}$ & $\mathrm{X}$ & $\mathrm{x}$ & $\mathrm{x}$ & $\mathrm{x}$ \\
\hline 62. & Accruals & 74 & & & & & \\
\hline 63. & Provisions & 75 & & & & & 24405 \\
\hline 64. & $\begin{array}{ll}\text { TOTAL } & \text { CURRENT } \\
\text { LIABILITIES } & \\
\end{array}$ & 78 & 73219 & 2365466 & 67199 & 88223 & 157808 \\
\hline 65. & TOTAL LIABILITIES & 79 & 117029 & 2403276 & 91604 & 112628 & 157808 \\
\hline 66. & $\begin{array}{llr}\text { NET ASSETS } & = & \text { TOTAL } \\
\text { ASSETS } & - & \text { TOTAL } \\
\text { LIABILITIES } & = & \text { EQUITY } \\
\text { INSTRUMENTS }\end{array}$ & 80 & 3487800 & 3657274 & 10715027 & 10551839 & 10479222 \\
\hline 67. & EQUITY INSTRUMENTS & 83 & $\mathrm{x}$ & $\mathrm{X}$ & $\mathrm{x}$ & $\mathrm{x}$ & $\mathrm{x}$ \\
\hline 68. & Reserves, funds & 84 & 3433022 & 3379733 & 10229856 & 10223341 & 10223341 \\
\hline 69. & Reported outturn & 85 & 6247 & 104,520 & 267,002 & 488,069 & 351,603 \\
\hline 70. & Reported outturn & 86 & & & & & \\
\hline 71. & $\begin{array}{l}\text { Economic outturn of the } \\
\text { financial year }\end{array}$ & 87 & 48531 & 173021 & 218169 & 159571 & 95722 \\
\hline 72. & $\begin{array}{l}\text { Economic outturn of the } \\
\text { financial year }\end{array}$ & 88 & & & & & \\
\hline 73. & $\begin{array}{lc}\text { TOTAL } & \text { EQUITY } \\
\text { INSTRUMENTS } & \end{array}$ & 90 & 3487800 & 3657274 & 10715027 & 10551839 & 10479222 \\
\hline
\end{tabular}

Annex no. 4. The economic outturn account - Pianu

\begin{tabular}{|c|c|c|c|c|c|c|c|}
\hline \multicolumn{8}{|c|}{ THE ECONOMIC OUTTURN ACCOUNT - Pianu } \\
\hline \multicolumn{8}{|c|}{ e } \\
\hline $\begin{array}{l}\text { Ref. } \\
\text { no. }\end{array}$ & INDICATORS & $\begin{array}{l}\text { Row } \\
\text { code }\end{array}$ & 2013 & 2014 & 2015 & 2016 & 2017 \\
\hline I. & B & 01 & & & & & \\
\hline 1. & OPERATIONAL REVENUES & 02 & 3042405 & 4162145 & 3903966 & 4815792 & 5468788 \\
\hline 2. & $\begin{array}{l}\text { Revenues from duties, taxes, } \\
\text { security contributions and other } \\
\text { budgetary revenues }\end{array}$ & 03 & 336334 & 47435 & 22193 & 45450 & 46400 \\
\hline 3. & Revenues from economic activities & 04 & 10399122 & 1696098 & 2155564 & 397855 & 1286464 \\
\hline
\end{tabular}




\begin{tabular}{|c|c|c|c|c|c|c|c|}
\hline 4. & Financing, subventions, transfers & 05 & 432519 & 542747 & 264518 & 404511 & 242859 \\
\hline & Other operational revenues & 06 & 14210380 & 6448425 & 6346241 & 5663608 & 7044511 \\
\hline II. & $\begin{array}{ll}\text { TOTAL } & \text { OPERATIONAL } \\
\text { REVENUES } & \\
\end{array}$ & 07 & & & & & \\
\hline 1. & OPERATIONAL EXPENSES & 08 & 1560692 & 1677604 & 2104860 & 2465834 & 3270065 \\
\hline 2. & $\begin{array}{l}\text { Wages and social security } \\
\text { contributions for employees }\end{array}$ & 09 & 388133 & 567300 & 523441 & 368369 & 442443 \\
\hline 3. & Subventions and transfers & 10 & 1776258 & 1688103 & 2004972 & 1735933 & 2033870 \\
\hline 4. & $\begin{array}{l}\text { Stocks, supplies, services from the } \\
\text { third parties }\end{array}$ & 11 & 11488321 & 43532 & 33089 & 3911023 & 248141 \\
\hline \multirow[t]{2}{*}{5.} & $\begin{array}{l}\text { Capital expenditure, depreciation } \\
\text { and provisions }\end{array}$ & 12 & & & & & 474 \\
\hline & Other operational expenditure & 13 & 15213404 & 3976539 & 4666362 & 8481159 & 5994993 \\
\hline \multirow[t]{3}{*}{ III. } & $\begin{array}{ll}\text { TOTAL } & \text { OPERATIONAL } \\
\text { EXPENDITURE } & \\
\end{array}$ & 14 & & & & & \\
\hline & $\begin{array}{lccc}\text { THE } & \text { OUTTURN } & \text { OF } & \text { THE } \\
\text { OPERATIONAL ACTIVITY } & \\
\end{array}$ & 15 & & 2471886 & 1679879 & & 1049518 \\
\hline & - EXCESS & 16 & 1003024 & & & 2817551 & \\
\hline IV. & - DEFICIT & 17 & & & & & \\
\hline V. & FINANCIAL REVENUES & 18 & 55186 & & & & \\
\hline \multirow[t]{3}{*}{ VI. } & FINANCIAL EXPENDITURE & 19 & & & & & \\
\hline & $\begin{array}{lccc}\text { THE } & \text { OUTTURN } & \text { OF } & \text { THE } \\
\text { FINANCIAL ACTIVITY } & \\
\end{array}$ & 20 & & & & & \\
\hline & - EXCESS & 21 & 55186 & & & & \\
\hline \multirow[t]{3}{*}{ VII. } & - DEFICIT & 22 & & & & & \\
\hline & $\begin{array}{l}\text { THE OUTTURN OF } \\
\text { CURRENT ACTIVITY }\end{array}$ & 23 & & 2471886 & 1679879 & & 1049518 \\
\hline & - EXCESS & 24 & 1058210 & 6150925 & 17912 & 2817551 & \\
\hline VIII. & - DEFICIT & 25 & 4468 & 4312 & 4778 & 87733 & 17211 \\
\hline IX. & EXTRAORDINARY REVENUES & 26 & & & & & \\
\hline \multirow[t]{3}{*}{$\mathrm{X}}$. & $\begin{array}{l}\text { EXTRAORDINARY } \\
\text { EXPENDITURE }\end{array}$ & 27 & & & & & \\
\hline & $\begin{array}{l}\text { THE OUTTURN FROM THE } \\
\text { EXTRAORDINARY ACTIVITY }\end{array}$ & 28 & 4468 & 4312 & 4778 & 87733 & 17211 \\
\hline & - EXCESS & 29 & & & & & \\
\hline \multirow[t]{4}{*}{ XI. } & - DEFICIT & 29.1 & & & & & \\
\hline & $\begin{array}{lll}\text { THE ECONOMIC } & \text { OUTTURN } \\
\text { (GROSS) }\end{array}$ & 29.2 & & & & & 1066729 \\
\hline & - EXCESS & 29.3 & & & & 2729818 & \\
\hline & - DEFICIT & 29.4 & & & & & \\
\hline \multirow[t]{3}{*}{ XII. } & Corporation taxes & 30 & & & & & \\
\hline & $\begin{array}{l}\text { THE ECONOMIC OUTTURN } \\
(\text { NET) }\end{array}$ & 31 & & 2476198 & 1684657 & & 1066729 \\
\hline & - EXCESS & 32 & 1053742 & & & 2729818 & \\
\hline
\end{tabular}

Annex no. 5. The economic outturn account - Horea

\begin{tabular}{|l|l|l|l|l|l|l|l|}
\hline $\begin{array}{l}\text { Ref } \\
\text { No. }\end{array}$ & INDICATORS & $\begin{array}{l}\text { Ro } \\
\mathbf{w} \\
\text { cod } \\
\mathbf{e}\end{array}$ & $\mathbf{2 0 1 3}$ & $\mathbf{2 0 1 4}$ & $\mathbf{2 0 1 5}$ & $\mathbf{2 0 1 6}$ & $\mathbf{2 0 1 7}$ \\
\hline A & B & C & 1 & 2 & 3 & 4 & 5 \\
\hline I. & OPERATIONAL REVENUES & 01 & & & & & \\
\hline 1. & $\begin{array}{l}\text { Revenues from duties, taxes, security } \\
\text { contributions and other budgetary revenues }\end{array}$ & 02 & $\begin{array}{l}260050 \\
8\end{array}$ & 2559224 & $\begin{array}{l}359049 \\
6\end{array}$ & $\begin{array}{l}335533 \\
6\end{array}$ & 4151077 \\
\hline 2. & Revenues from economic activities & 03 & 33096 & 28638 & 39904 & 27304 & 67354 \\
\hline 3. & Financing, subventions, transfers & 04 & $\begin{array}{l}182471 \\
0\end{array}$ & 3764610 & $\begin{array}{l}501496 \\
7\end{array}$ & $\begin{array}{l}385678 \\
9\end{array}$ & 4062836 \\
\hline
\end{tabular}




\begin{tabular}{|c|c|c|c|c|c|c|c|}
\hline 4. & Other operational revenues & 05 & 23528 & 533993 & 365008 & 368828 & 242073 \\
\hline & TOTAL OPERATIONAL REVENUES & 06 & $\begin{array}{l}448184 \\
2\end{array}$ & 6886465 & $\begin{array}{l}901037 \\
5\end{array}$ & $\begin{array}{l}760825 \\
7\end{array}$ & 8523340 \\
\hline II. & OPERATIONAL EXPENSES & 07 & & & & & \\
\hline 1. & $\begin{array}{l}\text { Wages and social security contributions for } \\
\text { employees }\end{array}$ & 08 & $\begin{array}{l}161901 \\
3\end{array}$ & 1815084 & $\begin{array}{l}222629 \\
7\end{array}$ & $\begin{array}{l}226557 \\
4\end{array}$ & 2907236 \\
\hline 2. & Subventions and transfers & 09 & 64267 & 51783 & 88571 & 119289 & 162694 \\
\hline 3. & $\begin{array}{l}\text { Stocks, supplies, services from the third } \\
\text { parties }\end{array}$ & 10 & 830164 & 1000948 & 935385 & $\begin{array}{l}112281 \\
7\end{array}$ & 1372661 \\
\hline 4. & $\begin{array}{l}\text { Capital expenditure, depreciation and } \\
\text { provisions }\end{array}$ & 11 & 11543 & 8283507 & $\begin{array}{l}549694 \\
3 \\
\end{array}$ & $\begin{array}{l}561558 \\
3\end{array}$ & 16791 \\
\hline 5. & Other operational expenditure & 12 & & & 32818 & & \\
\hline & TOTAL OPERATIONAL EXPENDITURE & 13 & $\begin{array}{l}252498 \\
7\end{array}$ & $\begin{array}{l}1115132 \\
2\end{array}$ & $\begin{array}{l}878001 \\
4\end{array}$ & $\begin{array}{l}912336 \\
3\end{array}$ & 4459382 \\
\hline III. & $\begin{array}{l}\text { THE OUTTURN OF THE OPERATIONAL } \\
\text { ACTIVITY }\end{array}$ & 14 & & & & & \\
\hline & - EXCESS & 15 & $\begin{array}{l}195685 \\
5\end{array}$ & & 230361 & & 4063958 \\
\hline & - DEFICIT & 16 & & 4264857 & & $\begin{array}{l}151500 \\
6\end{array}$ & \\
\hline IV. & FINANCIAL REVENUES & 17 & & & & & \\
\hline $\mathrm{V}$. & FINANCIAL EXPENDITURE & 18 & & & & & \\
\hline VI. & $\begin{array}{l}\text { THE OUTTURN OF THE FINANCIAL } \\
\text { ACTIVITY }\end{array}$ & 19 & & & & & \\
\hline & - EXCESS & 20 & & & & & \\
\hline & - DEFICIT & 21 & & & & & \\
\hline VII. & $\begin{array}{l}\text { THE OUTTURN OF THE CURRENT } \\
\text { ACTIVITY }\end{array}$ & 22 & & & & & \\
\hline & - EXCESS & 23 & $\begin{array}{l}195685 \\
5\end{array}$ & & 230361 & & $\begin{array}{l}4069395 \\
8\end{array}$ \\
\hline & - DEFICIT & 24 & & 4264857 & & $\begin{array}{l}151500 \\
6\end{array}$ & \\
\hline VIII & EXTRAORDINARY REVENUES & 25 & & & 170 & & \\
\hline IX. & EXTRAORDINARY EXPENDITURE & 26 & & & & & \\
\hline $\mathrm{X}$. & $\begin{array}{lccc}\text { THE } & \text { OUTTURN } & \text { FROM } & \text { THE } \\
\text { EXTRAORDINARY ACTIVITY } & \\
\end{array}$ & 27 & & & & & \\
\hline & - EXCESS & 28 & & & 170 & & \\
\hline & - DEFICIT & 29 & & & & & \\
\hline XI. & THE ECONOMIC OUTTURN (GROSS) & 29.1 & & & & & \\
\hline & - EXCESS & 29.2 & & & & & 4063958 \\
\hline & - DEFICIT & 29.3 & & & & $\begin{array}{l}151500 \\
6\end{array}$ & \\
\hline & Corporation taxes & 29.4 & & & & & \\
\hline XII. & THE ECONOMIC OUTTURN (NET) & 30 & & & & & \\
\hline & - EXCESS & 31 & $\begin{array}{l}195685 \\
5\end{array}$ & & 230531 & & 4063958 \\
\hline & - DEFICIT & 32 & & 4264857 & & $\begin{array}{l}151500 \\
6\end{array}$ & \\
\hline
\end{tabular}

Annex no. 6 The economic outturn account - Ceru Băcăinţi

\begin{tabular}{|l|l|l|l|l|l|l|l|}
\hline $\begin{array}{l}\text { Ref. } \\
\text { no. }\end{array}$ & INDICATORS & $\begin{array}{l}\text { Row } \\
\text { code }\end{array}$ & $\mathbf{2 0 1 3}$ & $\mathbf{2 0 1 4}$ & $\mathbf{2 0 1 5}$ & $\mathbf{2 0 1 6}$ & $\mathbf{2 0 1 7}$ \\
\hline A & B & C & 1 & 2 & 3 & 4 & 5 \\
\hline I. & OPERATIONAL REVENUES & 01 & & & & & \\
\hline 1. & $\begin{array}{l}\text { Revenues from duties, taxes, security } \\
\text { contributions and other budgetary }\end{array}$ & 02 & 680362 & 635933 & 1867692 & 723603 & 871854 \\
\hline
\end{tabular}




\begin{tabular}{|c|c|c|c|c|c|c|c|}
\hline & revenues & & & & & & \\
\hline 2. & Revenues from economic activities & 03 & & 1170 & 2636 & 3185 & 1935 \\
\hline 3. & Financing, subventions, transfers & 04 & 678 & 186826 & 6837275 & 56718 & 8232 \\
\hline \multirow[t]{2}{*}{4.} & Other operational revenues & 05 & 4626 & 6625 & 27283 & 6583 & 40095 \\
\hline & TOTAL OPERATIONAL REVENUES & 06 & 685666 & 830554 & 8734886 & 790089 & 922116 \\
\hline II. & OPERATIONAL EXPENSES & 07 & & & & & \\
\hline 1. & $\begin{array}{l}\text { Wages and social security contributions } \\
\text { for employees }\end{array}$ & 08 & 433409 & 448701 & 522527 & 581133 & 776662 \\
\hline 2. & Subventions and transfers & 09 & 8160 & 15026 & 65735 & 30350 & 27119 \\
\hline 3. & $\begin{array}{l}\text { Stocks, supplies, services from the third } \\
\text { parties }\end{array}$ & 10 & 113585 & 183482 & 1010472 & 178254 & 192020 \\
\hline 4. & $\begin{array}{l}\text { Capital expenditure, depreciation and } \\
\text { provisions }\end{array}$ & 11 & 81981 & 10044 & 6892591 & 148796 & 22037 \\
\hline \multirow[t]{2}{*}{5.} & Other operational expenditure & 12 & & & & & \\
\hline & $\begin{array}{l}\text { TOTAL } \\
\text { EXPENDITURE }\end{array}$ & 13 & 637135 & 657253 & 8491325 & 938533 & 1017838 \\
\hline \multirow[t]{3}{*}{ III. } & $\begin{array}{lccc}\text { THE } & \text { OUTTURN } & \text { OF } & \text { THE } \\
\text { OPERATIONAL ACTIVITY } & \\
\end{array}$ & 14 & & & & & \\
\hline & - EXCESS & 15 & 48531 & 173301 & 243561 & & \\
\hline & - DEFICIT & 16 & & & & 148444 & 95722 \\
\hline IV. & FINANCIAL REVENUES & 17 & & & & & \\
\hline V. & FINANCIAL EXPENDITURE & 18 & & & 25392 & 11127 & \\
\hline \multirow[t]{3}{*}{ VI. } & $\begin{array}{l}\text { THE OUTTURN OF THE FINANCIAL } \\
\text { ACTIVITY }\end{array}$ & 19 & & & & & \\
\hline & - EXCESS & 20 & & & & & \\
\hline & - DEFICIT & 21 & & & 25392 & 11127 & \\
\hline \multirow[t]{3}{*}{ VII. } & $\begin{array}{l}\text { THE OUTTURN OF THE CURRENT } \\
\text { ACTIVITY }\end{array}$ & 22 & & & & & \\
\hline & - EXCESS & 23 & 48531 & 173301 & 218169 & & \\
\hline & - DEFICIT & 24 & & & & 159571 & 95722 \\
\hline VIII. & EXTRAORDINARY REVENUES & 25 & & & & & \\
\hline IX. & EXTRAORDINARY EXPENDITURE & 26 & & & & & \\
\hline \multirow[t]{3}{*}{$\mathrm{X}}$. & $\begin{array}{lccc}\text { THE } & \text { OUTTURN } & \text { FROM } & \text { THE } \\
\text { EXTRAORDINARY ACTIVITY } & \end{array}$ & 27 & & & & & \\
\hline & - EXCESS & 28 & & & & & \\
\hline & - DEFICIT & 29 & & & & & \\
\hline \multirow[t]{4}{*}{ XI. } & THE ECONOMIC OUTTURN (GROSS) & 29.1 & & & & & \\
\hline & - EXCESS & 29.2 & & & & & \\
\hline & - DEFICIT & 29.3 & & & & 159571 & 95722 \\
\hline & Corporation taxes & 29.4 & & & & & \\
\hline \multirow[t]{3}{*}{ XII. } & THE ECONOMIC OUTTURN (NET) & 30 & & & & & \\
\hline & - EXCESS & 31 & 48531 & 173301 & 218169 & & \\
\hline & - DEFICIT & 32 & & & & 159571 & 95722 \\
\hline
\end{tabular}

